\title{
THE AGRIFOOD SYSTEM TRANSFORMATION IN NIGERIA: INSIGHTS FROM A HOUSEHOLD FOOD DEMAND MODEL
}

\author{
Adesola Adebola IKUDAYISI
}

\author{
Address: \\ Department of Agricultural Economics, University of Ibadan, Nigeria \\ E-mail: adesolaikudayisi@gmail.com
}

\begin{abstract}
Research background: The food system is central to a wide range of outcomes such as food security, nutrition and economic development. In this wise, the food systems must meet the needs of a growing and increasingly urbanized population. However, food system in developing countries is undergoing a rapid transformation towards high value products and food safety. Yet, the consumer demand drive towards the transformation has received much less attention. Hence, improvement in the agricultural and food systems must be viewed in the context of household food consumption patterns.

Purpose of the article: This paper examined household food demand and food choice preferences among urban households in southwest, Nigeria. Understanding Nigeria's Agrofood structure through urban eating pattern will proffer knowledge required for better policy design and implementation.

Methods: The paper applies a quadratic almost ideal demand system (QUAIDS) model to a cross-sectional household survey data from two urban areas, and estimate price and expenditure elasticities as indicators of household sensitivity to market shocks.

Findings \& Value added: Analysis of frequency distribution on urban household's preferences shows that convenience, availability, safety were important attributes influencing decisions to purchase foods. Demand estimations show positive expenditure elasticities for food groups with values close to unity. The animal-source foods and cereals were more expenditure-elastic in high urban areas (HUA) and low urban areas (LUA), respectively. All own-price elasticities are negative and LUA are more price-sensitive to most food groups compared to HUA. The price and expenditure results suggest that transformation of agro food products will come in place if convenience and food safety attributes are incorporated in food value chain.
\end{abstract}

Key words: elasticities; food expenditure; food system; QUAIDS; urban households JEL Codes: D12; O13; Q11

\section{INTRODUCTION}

The world's agrifood system responds to diverse climatic and agro-ecological conditions as well as market forces. Changing contexts such as resource availability, input costs, policy and institutional environment, and consumer preferences influence the structure of agrifood system (AFS). According to Chen et al., (2014), climate change, demographic change and economic change is responsible for the widespread changes in agricultural production systems. Possibly, changing climate in Africa countries has a strong impact on agricultural supply, thereby influencing the yields of farm products (Thornton $\boldsymbol{e t}$ al., 2010). The economic factor in terms of increasing income, per capita gross domestic product (GDP), is another driver of change in many low- and middle-income countries (LMICs) and this is further associated with urbanization (Chen et al., 2014). The striking changes in socioeconomic and demographic changes, larger proportion of consumers living in cities, in LMICs of Africa, particularly in Nigeria, result in changing dietary preferences with increased demand for animal-source foods in areas where levels of their consumption have been previously low (Gerland et al., 2014). The increasingly affluent urban population affect both supply and demand side of agricultural food products.

The emerging consumption patterns have probably created new opportunities for agro food. Also, food supply chains have lengthened and changed dramatically as the physical distance from farm to fork has increased with striking changes in food distribution. The emerging role of modern retail food outlets, growing preferences for convenience, food safety, quality and health procedures describe these changes (Mergenthaler et al., 2009; Crush and Frayne, 2011; Berkum, et al., 2017; Dolislager, 2017). In response to this trend, the rise of retail outlets particularly in urban areas introduced greater variety of foods with quality and food safety guarantees (Wertheim-Heck et al., 2015; Zhou and Staatz, 2016). However, Demmler et al., (2017) highlighted the nutritional outcomes of retail marketing. On the other hand, Smith and Vo (2017) discussed the resulting 
difficulties for developing countries in accessing high quality and diverse food products. Despite the growing recognition of the modernised food retails in some urban areas, Wertheim-Heck et al., (2015) emphasized that the traditional food markets (wet and farmer markets) still remain the dominant means of supply of mostly fresh foods in developing economies. With poor participation of rural farm populations in the growing urban markets in Africa, the AFS is characterized by the absence of specialization, low level of competitiveness for value addition and poor enabling environment (Zheng et al., 2015; Metu et al., 2016). These factors possibly limit availability of high-value agricultural products needed to meet the expanding demand of food by urban consumers. In Nigeria, Obayelu and Obayelu, (2014) attributed poor responses from some of the implemented agricultural programmes and policies in food chain to little or no consideration for value addition strategies needed to thrive the emerging urban food system. Also, the inability to rightly appropriate policy implications from household food demand responses towards effective value addition strategies was the stance of Metu et al., (2016). Evaluation of the impact of evolving AFS, in the context of food demand drive, requires an analytical study of food demand pattern that cuts across household demographics and different environments.

With the hypothesized importance of both supply and demand side factors in the food system transformation, most of the empirical studies on supply chain concentrate primarily on technological and chains methods towards future paths of the Agri-Food domain (El Bilali 2019; Lezoche et al., 2020). Also, the transformation of food systems through cross-sectoral collaboration (trade, food and nutrition security) and other emerging issues within agri-food markets centred on supply side (Borsellino et al., 2020). However, the contribution of the demand-side to AFS transformation which supposedly represents the feedback mechanism from other food chain has received much less attention. Besides, Pingali (2007) Tschirley et al. (2015) emphasised the importance of unfolding food demand patterns in driving the agrifood system transformation. Relatively few empirical studies have responded to issues of consumer demand, often with specific focus on some food products (e.g fruits and vegetables by Mergenthaler et al., 2009; Ekanem et al., 2020) and not on entire household diet. This is considered a research gap, because understanding the economic demand parameters of aggregate food is instructive for predictions of future development in agrifood system. This article addresses this gap empirically for urban Nigeria. Nigeria presents an interesting case study as a result of the pace and scale of transformation in economy and urbanization. Nigeria is considered as the Africa's next urban giant (UN, 2019). The economic performance in Nigeria has experienced a substantial economic growth, particularly in the food retail economy in sub-Saharan Africa due to its large consumer base. The point that food transformation is potentially demand-driven, household food demand response patterns remain a prerequisite for food and agricultural policies towards better contribution of local food economy to economic development.
In order to estimate household demand parameters for food, quadratic almost ideal demand system (QUAIDS) was employed. Most demand analyses generally produce demand parameters for highly aggregated urban and rural dichotomy, this study focus on two urban areas with different level of economic and urbanization processes. The cross sectional analysis builds on a survey of 445 households in southwest zone urban areas in 2017. Understanding what consumers want will allow food marketers offer products that meet these demands, which will help improve sales revenues and profits for producers. This is expected to lead to a vibrant Nigerian food sector while offering safe and healthy food for the populace.

\section{DATA AND METHODS}

\section{Study Area}

The study was conducted in Southwest Nigeria. It is one of the six geopolitical zones in the country which comprises of six states, Ondo, Oyo, Ekiti, Lagos, Ogun and Osun. Southwest zone is noted for its rapid level of urbanization owing to high concentration of urban activities (Ikwuyatum, 2016). Major urban cities have manufacturing sectors, financial institutions, trading corporations, food processing companies, organised food distribution and retail sectors (hyper and supermarkets and other essential grocery). The main occupation in this zone ranges through agriculture-related jobs, trading, manufacturing and white-collar jobs. The area is noted for its rapid infrastructural development combined with higher literacy rate than other zones as most of its urban areas had higher number of educational facilities (National Population Commission, NPC, 2006). These factors characterised the extent of urbanisation and rapid urban growth in the study area.

\section{Data}

A cross-sectional data from 445 households randomly selected through a multi-stage sampling procedure from two randomly selected urbanising states in southwest, Nigeria was employed. The two states namely Ekiti and Oyo are representative of the low urban area (LUA) and high urban area (HUA), respectively (National Population Commission, NPC, 2006). The grouping was based on respective states population size, economic activities and other administrative activities (Ikwuyatum, 2016; NPC, 2006). The most urbanized location within each of the sampled states was purposively selected on the basis of the administrative process and level of urbanisation. Households were randomly sampled from Enumeration Areas (EAs) mapped by National Population Commission which represented the primary sampling units used for 2006 population census in Nigeria. Following previous studies on food demand (Rizov et al., 2015; Van Oordt, 2016; Korir et al., 2018), information was collected through structured questionnaires at the household level. The data provide information about household head's socioeconomic characteristics, records of the expenditure and quantity of foods purchased by the households in a one-week period. For all the food purchased, information on respondents' perception on food choice attribute was collected. 


\section{Methods}

Consumer theory involves the procedure through which consumers make consumption decisions. This can be explained by choice of goods as influenced by prices, income and other non-financial attributes. This choice based on preferences likely reflect changing consumer tastes and quality as the income levels change (Grunert, 2006; Ogundari, 2012). Lancaster (1971) model incorporates the product attributes into the demand function. If $\mathrm{z}_{i j}$ represent measure of attribute $i$ within good $j$, such that demand for good $q$ expressed as a function of this attribute, then $z$ (convenience, taste, quality, availability etc.) and price $p i$ is given as Eq. $1-2$.

$$
\begin{array}{ll}
\text { Maximise } & U=U\left(z_{1}, \ldots, z_{n}\right) \\
\text { Subject to: } & P_{n} X_{n} \leq Y \\
& Z=B X \\
& \text { for } Z, X \geq 0 \\
& U(B X)=u(X)
\end{array}
$$

Where: $U$ utility

$P$ price of goods

$X$ quantity of goods

$Y$ income

$Z$ product attributes,

$B$ matrix of consumption technology,

$u(X)$ new utility function in terms of $X$.

The descriptive statistics for aggregate responses of urban household's preference for food choices is shown in Figure 1. It revealed that convenience attribute had the most significant influence (about 77 per cent) on choice of food among households. This corroborates Reardon and Minten (2011) that demand for convenience is reflected in the strong demand for instant/processed and prepared foods and in the expansion of supermarket and other modern retail outlets. This trend might be as a result of heterogeneity in urban lifestyle as well as changing occupational structure especially for women with respect to time saving food preparation. Appropriating this attribute in food value addition can lead to growth and diversification of agro food economies and further strengthening of rural-urban food linkages. About three quarters of household considered availability as a criterion for food choice which implies that consistent access to food supply would drive more demand for foods in urban areas. The price of food products determines to a greater extent the quantity of foods purchased. This economic assumption still holds as about 73.9 per cent of household considered price attribute in choice of food commodities (Korir et al., 2020). About 68 per cent of households indicated quality, taste and variety as a precondition for food choice. Olawuyi and Adeoye, (2018) highlighted the importance of these attributes in food safety and health outcomes particularly the prevalence of noncommunicable diseases and other diet-related diseases in urban areas of Nigeria. This offers a signal for food value chain actors in response to perceived health outcomes and socioeconomic status from quality measure.

This requires changes in marketing infrastructures such as cold chains, storage facilities and adequate market information along the chain. This would help sustain the shelf life of food products for better availability of food even during the off seasons. The findings established that urban household preferences and food purchase decisions are often not only influenced by price but by other nonprice attributes as Ojogho and Alufohia (2013) observed. Analysis of frequency distribution shows that convenience, availability, safety were important attributes influencing consumers' decisions to purchase foods. Understanding consumer motivations and knowing the relative importance of various food items consumed in urban areas are essential in improving market efficiency. Also, incorporating the observed food attributes into agrifood interventions would match urban consumer heterogeneity in food demand.

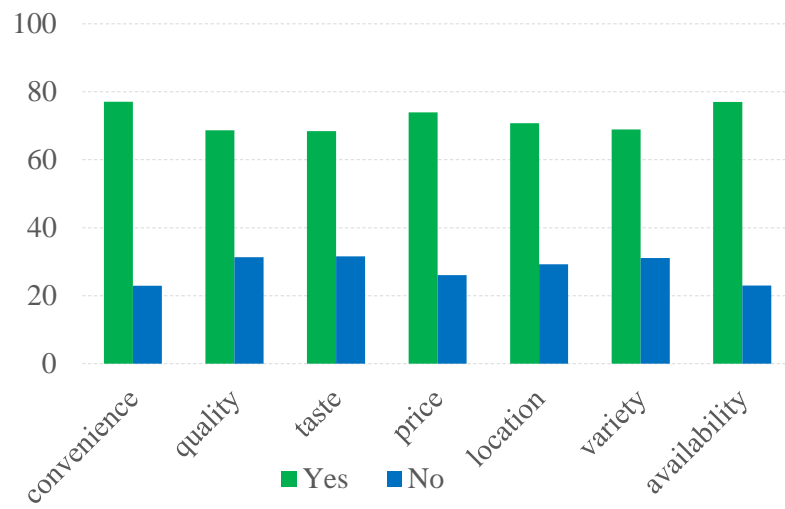

Figure 1: Perceptions of household's food choice

\section{Demand system model}

The quadratic almost ideal demand system (QUAIDS) model is a generalization of AIDS model due to the inclusion of the square of the logarithm of expenditure. This allows any given good to be a luxury at one level of expenditure and a necessity at another. This characteristic makes it well suited for household food demand with varying income level and explains the non-linear heterogeneous relationship between price and expenditure. In the extant literature, several studies have confirmed the appropriateness of QUAIDS in modelling food demand preferences (Garcia-Enriquez and Echevarria, 2015; Van Oordt, 2016; Mottaleb et al., 2017, Korir et al., 2020). The empirical specification of the QUAIDS budget share equations is given as Eq. 3 .

$$
\begin{aligned}
& w_{i}=\alpha_{i}+\sum_{j=1}^{n} \gamma_{i j} \ln p_{i}+\beta_{i} \ln \left[\frac{m}{a(p)}\right]+ \\
& \frac{\lambda_{i}}{b(p)}\left\{\ln \left[\frac{m}{a(p)}\right]\right\}^{2}+\sum_{i=1}^{n} \delta_{i s} Z_{s}+\varepsilon_{i}
\end{aligned}
$$

Where $w_{i}$ is the expenditure share allocated to each food group $i$,

$p_{i}$ the price of $i$ th food group,

$m$ total food expenditure,

$\alpha_{i}$ average value of budget share in the absence of price and income effects.

$\beta_{i}$ parameter that determines the expenditure elasticity

$\gamma_{i j}$ effects of cross price elasticity

$\lambda_{i}$ determine effects of quadratic term,

$\delta_{i s}$ vector of socioeconomic and demographic variables; 
$Z_{s}$ socioeconomic variables,

$\varepsilon_{i}$ error term

The 89 food items were grouped into seven food categories based on their nutritional content (Obayelu $\boldsymbol{e t}$ al., 2009; Udoh et al., 2013): cereals, roots and tubers, legumes, meat and its by-products, fruits and vegetables, fats and oils and miscellaneous food products. The miscellaneous group comprises products with some value addition such as bread, refined wheat, semovita, pastas, beverages, processed fruit drinks and confectionary foods. Due to differences in the measures of food acquisition, the physical quantities of food purchased were converted to kilograms following the specification of National Bureau of Statistics (NBS) food composition table. Also, seasonal variability effect may not be significant in this study since urban households are net food buyers.

\section{RESULT AND DISCUSSION}

The summary of the mean characteristics of household heads across the two urban areas is presented in Table 1. Majority of the household heads were male with about three quarters of them married. the average age of household heads across the two areas was 47 years. The mean household size for LUC and HUC was 5 and 4 people, respectively. About three-quarters of household heads in both locations had tertiary education while over three-quarters of them were members of a social organization. Average monthly income across urban areas were in the range from $48,848.85$ to $53,144.87$ Nigerian Naira (NGN) (USD 101.77-110.72). The income differential might likely be the variation in economic opportunities across the two urban areas. From the occupational structure, a larger percentage of household heads were into formal employments. These findings suggest socioeconomic inequality in the status of household heads within urban areas.

\section{Demand elasticities}

Price and income elasticities are estimated for seven food groups in order to characterize heterogeneous households' demand behaviour. Expenditure estimates for fat/oil and miscellaneous foods groups confirm the appropriateness of the demand model (QUAIDS) used (Table 2). It revealed the increased Engle flexibility characteristics of these products which further aids the understanding of the demand response to food supply chain as income changes. For example, fat and oil group changed from being a luxury (1.31) in LUA to a necessity good (0.61) in HUA as income level changes. Estimation results of expenditure elasticity from Table 2 revealed that across the urban areas, all the food groups had positive expenditure elasticities value, greater than unity, except the roots and tubers group. The disaggregated expenditure elasticity of cereal groups in the urban areas of Nigeria indicated a rise in consumption with increasing incomes particularly in less urbanised places. Accordingly, the expenditure elasticity for root and tubers was lower and those for more expensive products such as meat and processed food products are somewhat higher. This suggests low consumption of food products in their raw state as income rises which might result to a shift towards high value products due to urban lifestyles. This applies in particular to value addition of food products noted for ease of preparation and greater acceptability.

Further, expenditure elasticities for meat (2.45) and miscellaneous foods (2.11) groups were more elastic in HUA. This is consistent with literature that reported increased consumption of animal rich foods (meat, fish, eggs etc.) as wealthier households can afford more nutrient-rich foods (including animal-based proteins) than poorer households in Nigeria (Kuku-Shittu et al., 2013; Adetunji and Rauf, 2015; Ogbeide, 2015; Ikudayisi et al., 2019) and Kenya (Korir et al., 2020). Increased expenditure on high valued foods was also reported by Triphati and Srivastava (2011) in India attributed to desire for diversity. Increased intake of miscellaneous foods as evident in their high expenditure value in the HUA (2.11) suggests the role of value addition as food items in this category are mainly processed with convenience and minimal time of preparation. This was in line with de Brauw and Herskowitz, (2018) study which finds that elasticity of demand for this food group was highest for the relatively wealthy and in the urban South of Nigeria. Similar trend in high intake of processed and packaged foods relative to fresh food items was reported by Euromonitor (2012) in Nigeria. This finding corroborates the previously discussed empirical findings (Figure 1) that convenience attribute of foods might increase level of food demand. The expenditure patterns suggest potential market for these demand-led food products with policy tailored towards adding value for better acceptability and quality of locally produced foods.

The AFS sector as a whole would benefit from the expenditure elasticity of foods which was almost at the same level in the two locations. It revealed the quest for freshness, safety and quality to probably for health implication in boosting the micronutrient supply, as Figure 1 indicated. Expenditure elasticities of greater than one indicate that the observed rise in their demand is expected to rise substantially in the further process of economic development and as such supply chains will grow contributing to choice by convenience. In growing economies like Nigeria, substantial future demand growth can be expected for food products with high expenditure elasticities. Goods with high expenditure elasticities could create incentives for farmers and other supply chain actors to harness opportunities in emerging markets. With this evidence and an effort to emphasize value addition benefits within the marketing activities, the desired growth for agrifood chain can be achieved.

All of the own-price elasticities reported in Table 3 have the expected negative signs. This satisfied the negativity property of own-price effects and further confirmed the inverse relationship between price and quantity demanded across food groups. However, this condition did not hold in the compensated values for cereals group (0.18) in LUA and meat group (0.24) in HUA. This might probably be that households in LUA consume more of cereal (rice, maize, sorghum, maize flour, guinea corn, millet) as their preferred diet as observed by Korir et al., (2020). The meat intake in HUA could be attributed to changing preference for more protein intake, taste, convenience and quality. 
Table 1: Socioeconomic characteristics of Household Heads

\begin{tabular}{|c|c|c|c|c|c|c|c|}
\hline \multirow{3}{*}{$\begin{array}{l}\text { Variables } \\
\text { Sex }\end{array}$} & \multirow{3}{*}{$\begin{array}{l}\text { Description } \\
\begin{array}{l}\text { Household is male headed or otherwise (female } \\
\text { headed) }\end{array}\end{array}$} & \multicolumn{3}{|c|}{ Low Urban Area (LUA) } & \multicolumn{3}{|c|}{ High Urban Area (HUA) } \\
\hline & & \multirow[t]{2}{*}{ Mean } & \multicolumn{2}{|c|}{ Standard Deviation } & \multirow{2}{*}{ Mean } & \multicolumn{2}{|c|}{ Standard Deviation } \\
\hline & & & 0.67 & 0.47 & & 0.70 & 0.46 \\
\hline Age & Age of household head in years & & 47.25 & 9.60 & & 47.32 & 11.99 \\
\hline Marital status & $\begin{array}{l}\text { Household head is married or otherwise (single, } \\
\text { divorced and widowed) }\end{array}$ & & 0.76 & 0.43 & & 0.74 & 0.44 \\
\hline Household size & Number of persons in the household & & 4.70 & 1.54 & & 4.29 & 1.56 \\
\hline Membership in social organization & $\begin{array}{l}\text { Household head being in a social group } \\
\text { (professional, cooperative societies, religious, non- } \\
\text { governmental organization) or otherwise. }\end{array}$ & & 0.76 & 0.43 & & 0.79 & 0.41 \\
\hline Educational status & $\begin{array}{l}\text { Household head level of education being formal( } \\
\text { primary, secondary and tertiary) or otherwise(non- } \\
\text { formal) }\end{array}$ & & 0.77 & 0.42 & & 0.81 & 0.40 \\
\hline Average monthly income & $\begin{array}{l}\text { Income earned by household head on a monthly } \\
\text { basis in Naira }\end{array}$ & & 48848.85 & 16794.25 & & 53144.87 & 18465.58 \\
\hline Occupational status & $\begin{array}{l}\text { Occupational type of household head is in formal } \\
\text { sector(government, private organizations) or } \\
\text { otherwise (traders, farmers, artisans) }\end{array}$ & & 0.69 & 0.46 & & 0.64 & 0.48 \\
\hline
\end{tabular}

Source: Author's calculation

otherwise (traders, farmers, artisans)

Table 2: Expenditure Elasticities Estimates for Urban Households

\begin{tabular}{lrr}
\hline Food groups & Low Urban Area (LUA) & High Urban Area (HUA) \\
\hline Cereals & 2.37 & 1.37 \\
Roots and tubers & 0.45 & 0.41 \\
Legumes & 2.18 & 1.93 \\
Meat & 1.34 & 2.45 \\
Fat and oil & 1.31 & 0.61 \\
Fruits and vegetables & 1.08 & 1.06 \\
Miscellaneous foods & 0.37 & 2.11 \\
\hline
\end{tabular}

Source: Output from QUAIDS analysis 
Table 3: Own-Price Elasticity Estimates of Demand for Urban Households

\begin{tabular}{lrr}
\hline Food groups & Low Urban Area (LUA) High Urban Area (HUA) \\
\hline Uncompensated & & \\
Cereals & -0.40 & -0.41 \\
Roots and tubers & -0.85 & -0.92 \\
Legumes & -0.18 & -0.12 \\
Meat & -0.54 & -0.20 \\
Fat and oil & -0.39 & -0.41 \\
Fruits and vegetables & -0.27 & -0.21 \\
Miscellaneous foods & -0.19 & -0.52 \\
Compensated & & \\
Cereals & 0.18 & -0.11 \\
Roots and tubers & -1.00 & -0.85 \\
Legumes & -0.08 & -0.07 \\
Meat & -0.35 & 0.24 \\
Fat and oil & -0.34 & -0.39 \\
Fruits and vegetables & -0.09 & -0.02 \\
Miscellaneous foods & -0.18 & -0.42 \\
\hline So Oul
\end{tabular}

Source: Output from QUAIDS analysis.

For instance, rice, a major cereal food item mostly consumed across households in Nigeria particularly the imported type with more convenience attribute and stonefree is often preferred as compared to the locally produced rice with stones despite its taste and nutrient composition. This evidence points to the effect of harnessing food value addition strategies for food system transformation. The own-price effects are price inelastic i.e., households are less affected by price changes across the urban areas with the exception of roots and tubers group (compensated matrix) in LUA. Inelastic food groups suggest households might be unwilling to shift away with an occasion of price change because the preferred foods had relatively low substitute. The lower magnitude of the own-price elasticities may also be related to the relative importance of the food items across areas.

In the compensated matrix, the roots and tubers group were most sensitive (-1.00) in LUA while those in HUA was close to unity. Absolute values of food greater than one which indicated efficiency loss in supply chains, leading to higher prices, will decrease demand overproportionally as the case of roots and tuber groups. The root and tuber group most affected by changes in their own prices indicated that a percentage increase in the prices would lead to decrease in their quantity demanded by more than one percent, which was in line with their lower expenditure elasticities (Table 2). This finding corroborates those of Ikudayisi and Omotola (2020) and Erhabor and Ojogho (2011). Strategies that will reduce food prices is important for efficiency gains in supply chains, leading to lower prices, in response to increase demand and avalanche of income for producers. The price elasticities estimates showed that LUA are more pricesensitive to most food groups compared to HUA. The finding also suggests level of food insecurity among the vulnerable is occasioned by price effect.

\section{CONCLUSION AND POLICY IMPLICATIONS}

This paper examined household food demand and food choice preferences with implication on value addition in
Nigeria's AFS. The results of the empirical analysis present expenditure and price differential effects with possible market-based and value addition interventions that facilitate households access to food. This paper provides empirical insights into identification of different factors responsible for food choice from urban households with possible economic benefits on agro-food sector. Across urban areas, the food groups had expenditure elasticities value greater than one indicating luxury goods, except the roots and tubers group. The income effect suggests potential market for the demand of food products. The price elasticities estimates showed that low urban areas are more price sensitive to high value food groups compared to high urban areas. This price quality effect suggests policies strategies in terms of input costs in animal production, preservation for affordable food products. With this evidence, better integration of household demand responses to food policies and investment would improve affordability and stability of food supply. Improving the food economy hinges on better understanding of the price-income effect in restructuring value chain activities to match urban consumer heterogeneity. These, in turn, addresses the broader infrastructural needs of local food systems for better processing and preservation to meet the divergent needs of both producers and consumers in terms of profit maximization and cost minimization, respectively. Given that consumer preferences drives demand for local foods, it is expected that incorporating the observed attributes into agribusiness structure will improve agricultural sector's contribution to Nigeria's economy.

\section{REFERENCES}

ADETUNJI, M.O. AND RAUF, M.O. (2012). Analysis of household demand for meat in Southwest, Nigeria. Global Journal of Science Frontier Research Agriculture and Biology, 12 (1),1-29.

ASHAGIDIGBI, W. M., YUSUF, S. A., \& OKORUWA, V. O. (2012). Determinants of households' food 
demand in Nigeria. World Rural Observations, 4(4), 17-28.

BORSELLINO, V. SCHIMMENTI, E., \& EL BILALI, H. (2020). Agri-Food Markets towards Sustainable Patterns. Sustainability, 12, 2193; https://doi.org/10.3390/su12062193

CHEN, M.X., ZHANG, H., LIU, W.D., \& ZHANG, W.Z. (2014). The global pattern of urbanization and economic growth: evidence from the last three $\begin{array}{llll}\text { decades. } & \text { PLoS } & \text { One, }\end{array}$ https://doi.org/10.1371/journal.pone.0103799

CRUSH, J., \& FRAYNE, B. (2011). Supermarket expansion and the informal food economy in Southern African cities: Implications for urban food security. Journal of Southern African Studies, 37(4), 781-807. http://dx.doi.org/10.1080/03057070.2011.617532.

DE BRAUW, A., \& HERSKOWITZ, S. (2018) Income variability, evolving diets, and demand for processed foods in Nigeria. International Food Policy Research Institute, IFPRI Discussion Paper 01793.

DEMMLER, K. M., ECKER, O., \& QAIM, M (2017). Supermarket shopping and nutritional outcomes: a panel data analysis for Urban Kenya, World Development, $1-13$. http://dx.doi.org/10.1016/j.worlddev.2017.07.018

EL BILALI, H. (2019). Research on agro-food sustainability transitions: where are food security and nutrition? Food Security, 11:559-577. https://doi.org/10.1007/s12571-019-00922-1

ERHABOR, P. O. I., \& OJOGHO, O. (2011). Demand analysis for rice in Nigeria. Journal of Food Technology, 9(2), 66-74. DOI: 10.3923/jftech.2011.66.74

EUROMONITOR, (2012). Consumer lifestyles in Nigeria: consumer habits in context. Accessed online on December 9, 2012 at www.portal.euromonitor.com

GARCIA-ENRIQUEZ, J., \& ECHEVARRIA, C. A. (2015). Consistent estimation of a censored demand system and welfare analysis: The 2012 VAT Reform in Spain. Journal of Agricultural Economics, 1-24. https://doi.org/10.1111/1477-9552.12144

GERLAND, P., RAFTERY, A. E., SEVCIKOVA, H., LI, N., GU, D., SPOORENBERG, T., ALKEMA, L., FOSDICK, B. K., CHUNN, J., LALIC, N., BAY, G., BUETTNER, T., HEILIG, G. K., \& WILMOTH, J. (2014). World population stabilization unlikely this century. Science, 346(6206), 234-237. https://doi.org/10.1126/science.1257469

GRUNERT, K. G. (2006). How changes in consumer behaviour and retailing affect competence requirements for food producers and processors. Economía Agrariay Recursos Naturales, 6(11), 3-22. DOI: https://doi.org/10.7201/earn.2006.11.01

IKUDAYISI, A. A, OKORUWA, V. O., \& OMONONA, B. T. (2019). From the lens of food accessibility and dietary quality: Gaining insights from urban food security in Nigeria. Outlook on Agriculture: 48(4): 336-343. https://doi.org/10.1177/0030727019866462

IKUDAYISI, A. A., \& OMOTOLA, A. M. (2020). Complement-Substitution nexus in the Nigerian Diet: Policy gaps in nutrition. Agricultural and Resource $\begin{array}{lcc}\text { Economics; } & 6, & 37-49 . \\ \text { https://doi.org/10.51599/are.2020.06.01.03 }\end{array}$

DOI:

IKWUYATUM, G. (2016). Migration and urbanisation: exploring the factors of the nexus in Nigeria", International Journal of Humanities and Social Science, 6(8), 161-175.

KORIR, L., RIZOV, M., \& RUTO, E. (2018). Analysis of household food demand and its implications on food security in Kenya: an application of QUAIDS model. In Agricultural Economics Society 2018 proceeding of annual conference in Warwick University, Coventry, UK.

KORIR, L., RIZOV, M., \& RUTO, E. (2020). Food security in Kenya: Insights from a household food demand model. Economic Modelling, 92 (2020), 99108. https://doi.org/10.1016/j.econmod.2020.07.015

KUKU-SHITTU, O., MATHIASSEN, A., WADHWA, A., MYLES, L., \& AJIBOLA, A. (2013). Comprehensive Food Security and Vulnerability Analysis: Nigeria. IFPRI Discussion Paper 01275, July 2013

LANCASTER, K. (1971). Consumer Demand: A new approach. New York: Columbia University Press.

LEZOCHE, M., HERNANDEZ, J., DEL MAR ALEMANY D. M., PANETTO, H., \& KACPRZYK, J. (2020). Agri-food 4.0: a survey of the supply chains and technologies for the future agriculture. Computers in Industry, 117.103-187, https://doi.org/10.1016/j.compind.2020.103187

MATUSHKE, I., \& KOHLER, S. 2014. Urbanisation and Food Security, https://www.researchgate.net/publication/263590485

MOTTALEB, K. A., RAHUT, D. B., KRUSEMAN, G., \& ERENSTEIN, O. (2017). Evolving food consumption patterns of rural and urban households in developing countries: A Bangladesh case. British Food Journal. https://doi.org/10.1108/BFJ-12-20160620.

NATIONAL POPULATION COMMISSION, NPC, (2006). Population and Housing Census of the Federal Republic of Nigeria (Volume I), Priority Tables, NPC. Available at: http://www.population.gov.ng.

OBAYELU, A. E., OKORUWA, V. O., AJANI, O. I. Y. (2009). Cross-sectional analysis of food demand in the North Central, Nigeria. The quadratic almost ideal demand system (QUAIDS) approach. China Agricultural Economic Review, 1(2), 173-193. https://doi.org/10.1108/17561370910927426

OGBEIDE, O. A. (2015). Meat industry development in Nigeria: implications of the consumers' perspective. Mayfair Journal of Agribusiness Management, 1(1), 59-75.

OGUNDARI, K. (2012). Demand for quantity versus quality in beef, chicken and fish consumption in Nigeria. Revista De Economia E Agronegócio, 10(1), 29-50.

OJOGHO. O., \& ALUFOHAI, G. O. (2013). Impact of price and total expenditure on food demand in southwestern Nigeria, African Journal of Food, Agriculture, Nutrition and Development, 10(1), 4350-4363.

OKRENT, A., \& ALSTON, J. M. (2011). Demand for food in the United States. University of California, 
Davis, Robert Mondavi Institute. Center for Wine Economics, RMI-CWE Working Paper No. 1002.

OLAWUYI, A. T., \& ADEOYE, I. A. (2018). The prevalence and associated factors of noncommunicable disease risk factors among civil servants in Ibadan, Nigeria. PLoS ONE, 13(9), e0203587. DOI: 10.1371/journal.pone.0203587

PENDLETON, L. H., \& SHONKWILER, J. S. (2001). Valuing bundled attributes: A latent characteristics approach, Land Economics, 77, 118-129. DOI: $10.2307 / 3146984$

PINGALI, P., (2007). Westernization of Asian diets and the transformation of food systems: implications for research and policy. Food Policy, 32 (3), 281-298. https://doi.org/10.1016/j.foodpol.2006.08.001

REARDON, T., \& MINTEN, B. (2011). Surprised by supermarkets: diffusion of modern food retail in India. Journal of Agribusiness in Developing and Emerging Economies, $1(2)$ 134 161. https://doi.org/10.1108/20440831111167155

THORNTON, P. K., JONES, P. G., ALAGARSWAMY, G., ANDRESEN, J., \& HERRERO, M. (2010). Adapting to climate change: agricultural system and household impacts in East Africa. Agric. Syst. 103, 7382. https://doi.org/10.1016/j.agsy.2009.09.003

TRIPATHI, A., \& SRIVASTAVA, S. (2011). Interstate migration and changing food preferences in India, Ecology of Food and Nutrition, 50(5), 410-428. https://doi.org/10.1080/03670244.2011.604586

TSCHIRLEY, D. SNYDER, J., DOLISLAGER, M., REARDON, T. HAGGBLADE, S., GOEB, J., TRAUB, L., EJOBI, F., \& MEYER, F. (2015). Africa's Unfolding Diet Transformation: Implications for Agrifood System Employment. Journal of Agribusiness in Developing and Emerging Economies, $5(1), 1-48$.
UDOH, E. J., MBOSSOH, E. R., UDOH, E. S., \& AKPAN, S. B. (2013). The structure of food demand in urban city of Nigeria: An application of a Linearized Almost Ideal Demand System (LA/AIDS). Journal of Development and Agricultural Economics, 5(1):12-18. DOI: $10.5897 /$ JDAE12.042

VAN OORDT, M. L. (2016). A nutritional goods and a complete consumer demand system estimation for South Africa using actual price data. South African Journal of Economics and Management Sciences, 19(4), 615-629. http://dx.doi.org/10.17159/22223436/2016/v19n4a10

ZHENG, Z., HENNEBERRY, S. R., ZHAO, Y., \& GAO, Y. (2015). Income growth, urbanisation, and food demand in China. Selected paper prepared for presentation at the Agricultural and Applied Economics Association. AAEA Annual Meeting, San Francisco, CA.

ZHOU, Y., \& STAATZ, J, (2016). Projected demand and supply for various foods in West Africa: implications for investments and food policy. Food Policy, 61, 198212. https://doi.org/10.1016/j.foodpol.2016.04.002 